Viso - Cadernos de estética aplicada Revista eletrônica de estética

ISSN 1981-4062

No 17, jul-dez/2015

http://www.revistaviso.com.br/

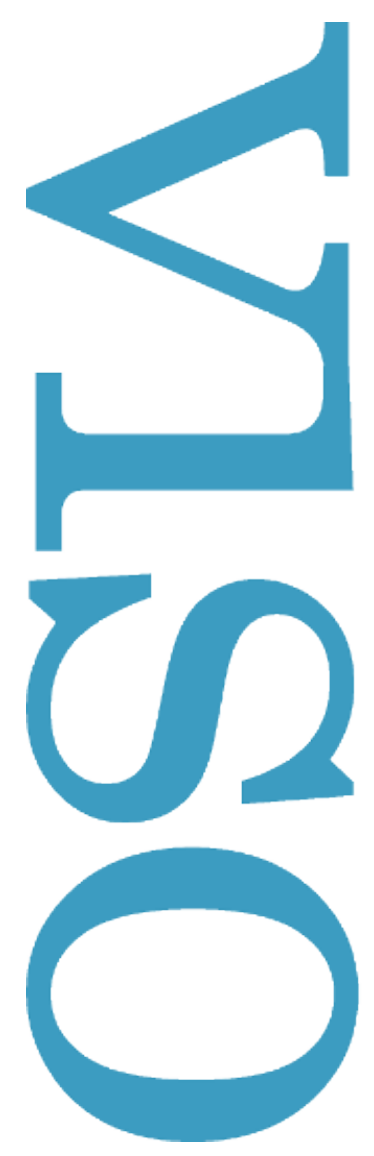

\title{
O domingo da vida e os dias da semana: Ironia e negatividade em Hegel e no romantismo Marco Aurélio Werle
}




\section{RESUMO}

O domingo da vida e os dias da semana: Ironia e negatividade em Hegel e no romantismo

O artigo trata da crítica hegeliana ao romantismo literário lemão, presente na resenha sobre a obra de Solger. Nessa resenha se apresenta uma análise da ironia sob o ponto de vista histórico, estético e religioso.

Palavras-chave: estética - Hegel - romantismo - ironia

\section{ABSTRACT}

The Sunday of Life and the Weekdays: Irony and Negativity in Hegel and in Romanticism

The article deals the Hegelian criticism of the German literary romanticism, present in the review of the work of Solger. This review contains an analysis of the irony from the historical, aesthetic and religious point of view.

Keywords: aesthetics - Hegel - romanticism - irony 
WERLE, M. A. "O domingo da vida e os dias da semana: Ironia e negatividade em Hegel e no romantismo". In: Viso: Cadernos de estética aplicada, v. IX, n. 17 (jul-dez/2015), pp. 148-165.

DOI: $10.22409 / 1981-4062 / v 17 i / 210$

Aprovado: 06.11.

2015. Publicado: 27.02.2016.

(C) 2016 Marco Aurélio Werle. Esse documento é distribuído nos termos da licença Creative Commons Atribuição-NãoComercial 4.0 Internacional (CC-BY-NC), que permite, exceto para fins comerciais, copiar e redistribuir o material em qualquer formato ou meio, bem como remixá-lo, transformá-lo ou criar a partir dele, desde que seja dado o devido crédito e indicada a licença sob a qual ele foi originalmente publicado.

Licença: http://creativecommons.org/licenses/by-nc/4.0/deed.pt_BR

Accepted: 06.11.2015. Published: 27.02.2016.

(C) 2016 Marco Aurélio Werle. This document is distributed under the terms of a Creative Commons Attribution-NonCommercial 4.0 International license (CC-BY-NC) which allows, except for commercial purposes, to copy and redistribute the material in any medium or format and to remix, transform, and build upon the material, provided the original work is properly cited and states its license.

License: http://creativecommons.org/licenses/by-nc/4.0/ 
O culto ... é em geral uma elevação a Deus a partir da ocupação do espírito com os interesses e preocupações temporais e desde os interesses puros do espírito. Mas é apenas o domingo da vida, seguem-se os dias de semana; o homem sai do gabinete da interioridade para o presente e o trabalho particulares e surge então a pergunta: como o reflexo do divino, que está presente no culto, se mostra nesse mundo? ${ }^{1}$

\section{Introdução}

Polêmica e complexa, a crítica de Hegel ao romantismo já recebeu a atenção de inúmeros estudiosos. Alguns a consideram injusta, pois seria feita do ponto de vista do idealismo e desconsideraria o âmbito específico da literatura e da imaginação, no qual se move o romantismo. No entanto, é preciso observar que não convém interpretá-la como se envolvesse apenas uma disputa de posições, como se Hegel tivesse uma visão de filosofia e os autores românticos outra ou como se Hegel fosse um "matuto", que não possui sentido para a ironia ou o humor, ao passo que os românticos seriam os "modernos", afeitos ao urbano ou à urbanidade e ao riso.

Parece-me antes que há uma série de contatos e cruzamentos intelectuais entre ambos, Hegel e o romantismo, no sentido de tentativas comuns de compreensão de fenômenos de época, bem como literários e universais. Considere-se, a título de exemplo, o senso histórico e a acolhida da obra de Shakespeare, bem como a tentativa de pensar os problemas estéticos de um ponto de vista mais amplo do que aquele colocado pelas poéticas tradicionais. Tudo isso permite contrastes produtivos e nos induz a tentar pensar essa questão para além de meras oposições ou de "partidos".

\section{A resenha da obra de Solger}

No texto sobre os escritos póstumos de Solger, publicado nos anos 20 em Berlim (portanto um texto da maturidade), Hegel articula seu exame do romantismo segundo duas frentes: uma consiste em verificar, de acordo com a história intelectual da Alemanha, como se tornou possível o ponto de vista do romantismo; a outra frente consiste em fazer uma apreciação especulativa e dialética dos princípios do romantismo e sua aplicação no campo da produção literária e de crítica poética e artística.

A resenha em si possui duas partes: dois artigos publicados na revista Jahrbücher für wissenschaftliche Kritik [Anuários de crítica científica]. ${ }^{2} \mathrm{O}$ primeiro artigo possui um tom mais histórico, voltado para uma delimitação do romantismo e sua postura em geral, ao passo que o segundo discute o conceito de ironia, associado à noção de especulação e de negatividade.

Os dois artigos apresentam estratégias distintas de abordagem da ironia por intermédio da obra de Solger: se no primeiro artigo Hegel pensa o romantismo e a ironia no quadro 
de um exame do que ele considera que são as crises da cultura alemã e desenvolve um exame do romantismo tanto em certas produções literárias de Kleist, Tieck e Novalis, no segundo artigo, ao contrário, a ironia é avaliada no horizonte de uma discussão da presença da infinitude na finitude. Hegel sustenta, nesse segundo momento, que Solger já lidava com a noção especulativa da negação da negação, embora nunca a tenha tematizado explicitamente. A estratégia consiste em indagar a natureza desse infinito que se manifesta na ironia, sendo que o fio mobilizado por Hegel é de ordem religiosa. Aqui entra a distinção entre o domingo da vida e os dias da semana, à qual aludi na epígrafe acima e que retomarei mais adiante.

Mas, o que significa para Hegel o romantismo? Que tipo de romantismo está sendo referido, ou melhor, com qual versão de romantismo lida Hegel? Na verdade, não há na resenha menção direta ao termo romantismo, no sentido de um determinado movimento ou fenômeno cultural de uma época, tal como o mesmo se tornou conhecido de $1830 \mathrm{em}$ diante. Hegel se refere antes a uma certa tendência intelectual que se desenvolveu no fim do século XVIII, na qual são agrupados fenômenos como a revista Ateneu (17981800) e os contos de Hoffmann (1814-20). Esses fenômenos são muito distantes um do outro, em termos das datas de surgimento e mesmo de proveniência intelectual, mas formam aos olhos de Hegel uma figura temporal e histórica mais ou menos coesa. Com efeito, o romantismo é para Hegel uma "figura" [Gestalt] cultural e histórica, a qual deve, por conseguinte, ser apreciada de um ponto de vista especulativo, de acordo com sua gênese fenomenológica. Na verdade, Hegel antecipa a concepção do romantismo tal como o mesmo se tornou conhecido posteriormente na história artística e literária, como tendo gerado uma nova forma de arte, em suma, uma nova figura estética que se espalhou por toda a Europa e pelo mundo.

Uma breve observação sobre o autor que é o assunto da resenha: Carl Friedrich Ferdinand Solger nasceu em 1780 e morreu em 1819, mesmo ano em que Hegel chegou a Berlim para assumir o posto na universidade de Berlim, vago desde a morte de Fichte. Em seus Cursos de estética, Hegel inclusive lamenta a morte prematura de Solger. Os cursos de estética, a saber, foram proferidos entre 1820-29, sendo que na resenha, de 1826, Hegel procura claramente ressaltar a obra de Solger como o verdadeiro inventor da ironia, negando, portanto, a paternidade dessa noção ao romantismo. ${ }^{3} \mathrm{~A}$ crítica que se esboça na resenha a Solger é a mesma que anos mais tarde penetra na publicação dos Cursos de estética, organizada em dois volumes, entre 1835-37, pelo aluno de Hegel, Heinrich Gustav Hotho. Na resenha, por vezes é difícil reconhecer o destinatário dos comentários de Hegel, uma vez que a coletânea resenhada inclui também uma correspondência entre Solger e o romântico Tieck, além de ter sido editada pelo próprio Tieck e Raumer, nesse mesmo ano de 1826. 


\section{O romantismo como a segunda crise da literatura alemã}

Hegel inicia sua resenha com um interessante diagnóstico acerca do desenvolvimento da cultura alemã desde meados do século XVIII até a virada para o século XIX. A fim de situar a obra juvenil de Solger - produzida no início do século XIX, momento efervescente da cultura alemã, quando já tinham surgido as principais obras do assim chamado romantismo de Jena - Hegel se propõe, com base em juízos do jovem Solger, a reconstituir o "tom e a direção peculiares daquela época". ${ }^{4}$ Deste modo, começa ressaltando dois aspectos que considera como sendo as duas crises na literatura alemã. ${ }^{5}$

1) A primeira crise recai na época da juventude de Goethe, caracterizada pela busca de uma orientação desde uma situação caótica. Hegel tem aqui em mente as considerações da obra autobiográfica de Goethe, intitulada Poesia e verdade. ${ }^{6}$ A saída que Goethe encontrou em sua juventude e que ao mesmo tempo permitiu que se afirmasse como escritor não só na literatura alemã, mas na europeia, foi ater-se a uma referência artística e poética dotada de um conteúdo interior e próprio. Esse conteúdo não estava disponível na Alemanha, e sim teve que ser importado, receber um impulso da Inglaterra, a saber, da obra de Shakespeare. ${ }^{7}$ A descoberta de Shakespeare, por sua vez, pelo personagem Meister é apresentada de modo exemplar em Os anos de aprendizado de Wilhelm Meister, obra também referida por Hegel.

2) A segunda crise diz respeito às consequências das soluções encontradas na primeira crise. Pois, com a abertura inicialmente promovida na cultura alemã, o entusiasmo por Shakespeare ampliou-se na direção dos mais variados assuntos poéticos de diferentes nações e proveniências (Dante, Holberg, Nibelungos e Calderon). Entretanto, Hegel arremata dizendo: "tal como a primeira crise buscava um conteúdo [Gehalt] e o elaborava e mostrava à luz do dia, diante do incômodo [Überdruss] decorrente do que é formal [Formellen], ligava-se inversamente com essa ampliação do gosto por formas e peculiaridades estrangeiras o fato de que o sentido para o conteúdo [Gehalt] e assunto [Inhalt] se contraiu na abstração subjetiva, em um tecer destituído de forma do espírito, fazendo inclusive com que o mesmo tivesse que se afastar do gozo e da valorização do humor e do chiste comum". ${ }^{8}$

Detenhamo-nos por um momento neste diagnóstico hegeliano para verificar o que ele nos revela. Hegel nos fornece aqui uma interpretação penetrante do desenvolvimento da cultura estética alemã. Como se sabe, inúmeros foram os combates travados pela estética alemã nascente com o chamado classicismo francês, a fim de conseguir uma afirmação nacional. Esse período pode ser chamado de "pré-romantismo", ainda que essa noção seja altamente problemática, pois abriga uma projeção retrospectiva e reduz a originalidade do Sturm und Drang. Acrescente-se que o Sturm und Drang teve sua origem por volta de 1770, sendo o romance de Goethe, intitulado Os sofrimentos do jovem Werther, de 1774, sua expressão literária máxima. Mas, desde os anos 50 do século XVIII já se destacavam intelectuais como Baumgarten, Winckelmann e Lessing. 
Na época a Alemanha já respirava novos ares e se movia na direção da consolidação de um conteúdo próprio e válido para a arte nacional.

Essa renovação se iniciou com Lessing e Winckelmann, cada um a seu modo desenvolvendo novas perspectivas e imprimindo uma nova vitalidade à cultura alemã e européia em geral. Lessing atuou de modo primoroso no campo da crítica literária e teatral, apoiando-se em Diderot, e procurando defender que o drama e a arte em geral tivessem uma relação efetiva com a vida, para além do formalismo preconizado pelos modelos franceses. Já Winckelmann descobriu a Antiguidade, abrindo uma perspectiva propriamente histórica de apreciação da arte. Hegel considera nos Cursos de estética que Winckelmann descobriu um "novo órgão de apreciação da arte", ou seja, o efeito de Winckelmann ultrapassa enormemente sua interpretação pura e simples dos gregos. Sua novidade é antes a de introduzir uma série de novos parâmetros, seja de apreciação artística seja de classificação dos grandes movimentos da história da arte. Lembremos das designações "clássico" e "romântico", tributárias da reordenação winckelmanniana da relação entre antigos e modernos. A partir desses dois autores surgem então Herder, Goethe, Schiller, dentre outros que continuaram na mesma direção.

Hegel interpreta todos esses esforços de pensamento como uma revitalização e, principalmente, como estabelecimento do princípio da subjetividade livre na arte. No entanto, a pergunta que se põe é: como se desdobrou e se desenvolveu essa subjetividade? E a resposta principal é que ela desembocou na abstração subjetiva e no tecer destituído de forma. E o que significam esses termos? Significam que Hegel detecta no romantismo um duplo movimento: de um lado há sem dúvida uma legitimidade no romantismo, que consiste em assumir o ponto de vista da subjetividade emergindo de uma série de esforços produtivos e críticos da época. O romantismo, portanto, se beneficia, desse movimento e se legitima por meio dele. Por outro lado, porém, o problema reside no modo como essa subjetividade foi desenvolvida e perpetuada, ou melhor, como foi deturpada desde sua origem "substancial", o que significa, desde sua gênese histórica e cultural, desembocando assim na abstração. $O$ termo "abstração" sempre tem um sentido preciso em Hegel: significa o fato de que se trata de um desdobramento unilateral (da subjetividade), de um abstrair raciocinante, segundo o entendimento, de um aspecto apenas, donde o surgimento do formalismo. Tudo estaria em seu devido lugar se o desenvolvimento da subjetividade não se encaminhasse para uma abstração e sim se desenvolvesse para uma concreção.

Com isso podemos notar que o problema hegeliano com o romantismo não é tanto com o princípio da subjetividade como tal, pois se trata de um fenômeno inegável da época moderna, mas com um certo desdobramento da mesma, rumo à infinitude vazia. Falta ao romantismo a percepção de que a subjetividade deveria cuidar tanto do domingo da vida quanto dos dias de semana, a saber, do descanso (ou "lazer", como diríamos nós hoje) e do trabalho [Werktage], e não apenas se entregar aos voos da fantasia, aos dias da imaginação. Pois, a subjetividade é a negação (portanto, concreção) da substância e não 
uma dimensão autônoma por si só.

Ao orientar as lutas da geração da juventude de Goethe por um conteúdo autêntico e próprio na direção de uma subjetividade formal, o romantismo acaba por dar um passo retrógrado, muito embora se tenha interpretado a "emancipação" da subjetividade como a grande contribuição do romantismo para a modernidade. Para Hegel, entretanto, o romantismo provoca a mesma alienação e estranhamento que os padrões franceses haviam provocado em meados do século XVIII na Alemanha e que, não obstante, eram defendidos como válidos para a Alemanha, por exemplo, por autores como Gottsched. Hegel considera que a nação alemã antes perdeu do que ganhou com a teoria da "poesia da poesia" (concepção defendida, entre outros, por A. Schlegel em sua Kunstlehre [Doutrina da arte] e por Novalis em Pólen) e com um círculo de poetas que mistificaram o público e a si mesmos com produções sem núcleo e consistência. ${ }^{9}$

Certamente o romantismo, no caso dos autores do primeiro romantismo, possui uma compreensão distinta deste desdobramento da cultura alemã. Tanto Hegel quanto os românticos partem das conquistas de Kant, mas no caso do romantismo a compreensão não passa pela fixação de um conteúdo, tal como insiste Hegel, mas no desdobramento de um plano da liberdade subjetiva que se coloca acima do conteúdo. A insistência num desdobramento da imaginação e da genialidade atesta essa compreensão. Sob a ótica do romantismo, há uma libertação gradual da humanidade, desde o século XVIII, por intermédio de fenômenos como a linguagem e a imaginação, sendo isso precisamente a ser expandido e difundido em termos intelectuais e literários.

O efeito do romantismo não se estendeu apenas para a Alemanha, mas estabeleceu um novo modo de apreciar e criticar obras de arte que, aos olhos de Hegel, comete uma série de equívocos. Hegel se detém no modo como Ludwig Tieck aprecia Shakespeare e Goethe. No caso de Shakespeare, Hegel ridiculariza a maneira como Tieck vê um declínio da poesia dramática por não possuir mais o mesmo tipo de palco da época de Shakespeare. Tieck desconsideraria a recepção que se operou na Alemanha por Goethe e A. Schlegel da obra de Shakespeare. ${ }^{10}$

\section{A ironia como vaidade subjetiva}

Se nos voltarmos agora para a apreciação especulativa do romantismo, temos que Hegel considera a ironia como seu princípio estruturante. Ela é definida por Hegel como sendo "a vaidificação [Vereitelung] consciente de si do que é objetivo". ${ }^{11}$

Em seu livro O gênio romântico, Márcio Suzuki considera que Hegel não compreende a ironia romântica de modo apropriado, principalmente quando procura separar a seriedade da comicidade ou do humor. ${ }^{12}$ No entanto, parece-me que o problema propriamente hegeliano não é tanto o da separação dessas esferas, no sentido de 
princípios que designam atitudes humanas ou comportamentos no plano da objetividade ou da subjetividade humana. Para além do ponto de vista dos estados de ânimo e comportamental, Hegel tem em vista o carácter especulativo, metafísico e histórico na base dessas instâncias éticas.

E é isso justamente que Hegel procura ressaltar no segundo artigo sobre Solger, a saber, que o princípio da ironia decorre de um desenvolvimento metafísico do espírito, de consequências muito mais profundas do que se pode imaginar à primeira vista. A chave interpretativa hegeliana é de ordem religiosa e mitológica e a pergunta central que se deve fazer é: será que o homem consegue em sua vida finita alcançar o divino nele mesmo? Caberia indagar se esse divino possui uma natureza que permite ser sustentada o tempo todo em sua "pureza" no campo das atitudes cotidianas do homem. E é aqui que ganha relevância a distinção entre o domingo da vida e os dias de feriado. A ironia nos remete para o campo da relação humana com o mito e a religião.

Em muitos momentos Hegel emprega o termo misticismo e mitificação para caracterizar a poesia e o modo de pensar românticos, por exemplo, ao referir-se ao misticismo arbitrário de Heinrich von Kleist, na peça o Príncipe de Homburg (1810). Aqui o autor teria confundido o aspecto do carácter sólido que deve possuir um príncipe, ao tratá-lo como um doente sonâmbulo. ${ }^{13}$ Com efeito, nessa peça, baseada num episódio da Guerra entre a Prússia e a Suécia, a saber, a batalha de Fehrbellin, de 1675, trata-se basicamente do conflito decorrente da ação do príncipe de Homburg e também general da cavalaria prussiana de atacar o exército sueco, à revelia da ordem superior do príncipe eleitor de Brandenburgo.

Nessa peça é abordado um tema típico de outras obras de Kleist: a alternativa entre a liberdade e a lei, isto é, entre o indivíduo e o Estado, e isso no âmbito de uma decisão a ser tomada pelo próprio indivíduo em relação a si mesmo. Segundo Hermann Reske, na peça de Kleist há uma constante oscilação entre o plano da realidade e do sonho: "O príncipe explica a realidade segundo a sua existência de sonho; mas a realidade comprova que sua existência de sonho não é sua verdade interior". ${ }^{14}$ Segundo Jochen Schmidt, com essa peça Kleist se opôs profundamente à ética dos oficiais prussianos e à imagem que os mesmos tinham do herói prussiano, desde o século XVII. E isso se tornou ainda mais grave porque Kleist descendia de uma família da nobreza militar prussiana. ${ }^{15}$ Aliás, a tese geral do livro de Jochen Schmidt é de que todas as peças dramáticas de Kleist lidam com a situação "dramática" pela qual passou sua família com o declínio da Prússia nas guerras com Napoleão. ${ }^{16} \mathrm{O}$ suicídio de Kleist se explicaria em parte por esse fato marcante, pois para ele e seus parentes era inconcebível que um nobre, para sobreviver, tivesse que se resignar a uma ocupação burguesa.

O alvo de Hegel nessa peça é o carácter instável e marcado por "fragilidades humanas" do príncipe ${ }^{17}$, que logo na primeira cena da peça aparece em estado de sonho. A seguir, resolve atacar os suecos, entrando por fim em desespero, ao saber de sua condenação 
à morte pelo desrespeito à ordem superior, ajoelhando-se e chorando diante da sobrinha do príncipe eleitor, Natalia (que ele acredita ser sua noiva), recebendo, por conseguinte, dela e do príncipe eleitor a compaixão. O príncipe eleitor, disposto a anistiá-lo, passa a responsabilidade da decisão sobre seu destino ao próprio príncipe, que acaba por se condenar a si mesmo. No fim da peça, porém, o príncipe é salvo porque o príncipe eleitor rasga a sentença da condenação. Hegel se refere também a esse personagem ao tratar do caráter moderno ${ }^{18}$, no contexto de abordagem da autonomia do caráter em Shakespeare, no terceiro capítulo da forma de arte romântica, pois justamente os caracteres shakespeareanos são decididos e resolutos, ao contrário dos de Kleist, que possuem inclusive traços de covardia.

Esse adjetivo "místico" não deve ser tomado num sentido apenas metafórico e pejorativo, como se fosse um adjetivo qualquer empregado para descaracterizar e rebaixar o romantismo. Pelo contrário, Hegel emprega esse termo num sentido técnico e preciso, o que apenas se compreende quando se examina a maneira como Hegel situa o aparecimento do princípio da ironia desde uma relação do homem com o elevado e o divino (de matrizes religiosas, assunto do segundo artigo da resenha).

Voltando novamente ao caso de Kleist, pode-se dizer que Hegel se opõe ao modo como esse escritor concebe suas intrigas e encaminha os desenlaces. Por exemplo, a novela Michael Kohlhaas, de 1808, apresenta o conflito entre a nobreza e a burguesia de um modo bastante próximo ao modo como Schiller concebeu sua intriga em Os bandoleiros. Trata-se da "lei do coração", criticada por Hegel na Fenomenologia do espírito, isto é, a figura do rebelde que tenta, com a ajuda de um grupo de salteadores, fazer justiça com as próprias mãos, mas acaba por gerar novas injustiças. E no desenlace a essa novela, Kleist lança mão do recurso ex machina do bilhete da cigana, que esta confia a Kohlhaas e Ihe permite então, pelo menos no plano ideal, realizar a vingança da injustiça de que é vítima, praticada pelo príncipe eleitor da Saxônia na corte de Dresden. Isso ocorre na última cena da novela, quando Kohlhaas engole o bilhete segundos antes de ser decapitado, diante dos olhos estarrecidos do príncipe-eleitor. Esse bilhete conteria informações preciosas sobre o Estado da Saxônia e que o príncipe-eleitor procura em vão adquirir para si. ${ }^{19}$ Com efeito, aos olhos de Hegel certamente é inteiramente inverossímil o modo como Kleist apresenta a exagerada importância que o príncipeeleitor da Saxônia dá a um bilhete de cigana. Pois, os interesses e os destinos de um Estado na realidade objetiva dependem antes de questões objetivas de um governo prudente do que de revelações "astrológicas" de uma cartomante.

Assim, o termo "misticismo arbitrário" [wirkürlicher Mystizismus] é empregado por Hegel num sentido bem preciso: não apenas o carácter místico das fabulações de Kleist é recriminado, mas principalmente o fato de ser "arbitrário", isto é, ser introduzido de modo artificial na trama. Isso significa um desvio de rota ou uma exacerbação em relação ao que significa a presença da subjetividade no interior do ser humano e no âmbito das relações efetivas da ação humana. Expressa a incapacidade humana de lidar com 
situações verdadeiras e reais e ao mesmo tempo denuncia uma confusão entre a realidade e as invenções arbitrárias ou mistificadoras. ${ }^{20}$

Essa questão da origem lógica e especulativa da ironia e do princípio da negatividade presente na obra de Solger é examinado por Hegel no segundo artigo de sua resenha. É ali que procura situar no interior da história do pensamento o modo de afirmação da ironia como princípio. Se para o romantismo, conforme a leitura de Márcio Suzuki, a ironia significa recuperar uma dimensão ética das virtudes, no sentido da civilidade romana defendida entre outros por Cícero, para Hegel, ao contrário, a verdadeira gênese do romantismo há de ser procurada no terreno da religião e do mito, uma vez que o assunto se refere ao modo de como se apresenta o divino no homem.

\section{A estética como o domicílio da ironia}

A partir do fulcro da subjetividade, o romantismo se faz valer principalmente no terreno das questões estéticas, embora tenha ao mesmo tempo uma pretensão ética. Nos Cursos de estética, Hegel afirma que o fantástico deve experimentar uma correção necessária na vida doméstica e cotidiana. ${ }^{21}$ Nesse trecho é "ironizada" não uma obra propriamente romântica, mas Os anos de aprendizado de Wilhelm Meister, na qual Hegel enxerga elementos claramente românticos, fato que também foi visto assim pelo romantismo nascente, no texto Conversa sobre a poesia, por Friedrich Schlegel. A crítica central de Hegel é que o romance de Goethe ressalta demasiadamente as relações meramente prosaicas, dando um destaque lírico para eventos que mereceriam antes um tratamento cômico, tal como o fez Cervantes com o Don Quixote. Do ponto de vista estético, na contraposição entre o domingo da vida e os dias da semana ressoa o veredicto hegeliano de que "o fantástico deve experimentar ... a correção necessária" 22 no âmbito da vida cotidiana e doméstica.

Quando Hegel se opõe às obras poéticas românticas e as acusa de falta de caráter, é preciso compreender essa oposição no horizonte da teoria estética da ação na arte e, em especial, da ação na poesia dramática. Em primeiro lugar, Hegel considera que o modo mais eficaz de as potências éticas (o divino no mundo) agirem e se manifestarem na arte passa pela presença do pathos no peito humano. É isso que move os seres humanos na vida e não a variedade subjetiva de atitudes e comportamentos (o mero divino no sujeito): "O pathos constitui, pois, o verdadeiro ponto central, o autêntico domínio da arte; a exposição dele é o que principalmente atua e produz efeito na obra de arte, assim como no espectador ... o pathos move porque é a potência em si e para si na existência humana". ${ }^{23}$ Diante desse aspecto da ação, não cabe fazer do pathos um mero capricho subjetivo e oscilante: "a poesia mais recente elevou-se a uma fantasmagoria e mentira infinita". ${ }^{24}$ No fim do capítulo sobre o caráter, Hegel rejeita justamente o recurso às forças "transcendentes" (magia, fantasmagoria, etc.) a determinarem o caráter ${ }^{25}$, o que pode ser remetido sem dúvida a obras literárias como o conto O pequeno Zacarias de 
Hoffmann e aos contos de Ludwig Tieck. Hegel chega mesmo a afirmar que a ironia é uma falsa teoria ${ }^{26}$, pois seduziu os poetas a introduzirem nos caracteres uma diversidade que não converge com nenhuma unidade, de modo que "todo caráter se destrói enquanto caráter". ${ }^{27}$

Mas como, na época pós-kantiana, a ironia encontrou na estética seu domicílio mais próprio? Hegel explicita o mecanismo de funcionamento da ironia a partir de sua base filosófica expressada pela identidade eu=eu de Fichte. ${ }^{28}$ Esse eu seria essencialmente abstrato e para ele nada pode ser considerado como sendo em si e para si: tudo para ele é aparência. No entanto, esse eu não pode permanecer nesse estado e por isso é preciso saber que tipo de realidade ele possui e que tipo de autonomia lhe é inerente. $\mathrm{Na}$ abstração teórica o eu=eu pode sem dúvida ser decretado, mas é necessário conferir como vive esse eu de fato, tanto em sua vida privada como pública. Para Hegel, a saída do romantismo para esse impasse será conceber o indivíduo vivo como um artista que, devido à sua excelência, é dotado de uma genialidade divina. Essa postura, porém, tende logo a enfrentar dificuldades de adaptação e de aceitação na vida social, sendo que o eu acaba por se revoltar contra o mundo, uma vez que os outros homens supostamente não conseguiriam alcançar esse ponto de vista elevado.

Dessa situação surgem outros dois conceitos: a vaidade e a nostalgia como formas imediatas da ironia, as quais exprimem uma espécie de antítese e dilaceramento e são frutos da cisão experimentada na realidade. A vaidade se refere ao eu emancipado, ao passo que a nostalgia se refere ao sentimento fracassado desse eu insatisfeito diante da objetividade. A vaidade anseia por um mundo melhor, mas que infelizmente nunca se realiza. A saída para essa situação torna-se então um tipo de afastamento do real: o culto doentio da bela alma. ${ }^{29}$ Como forma de arte, a ironia se aproxima assim do cômico, uma vez que uma de suas armas é "rir do mundo". Mas, assim, ela não realiza o verdadeiro cômico, que consiste antes em saber rir de si mesmo ou de algo objetivo que merece se destituir em si mesmo. ${ }^{30}$

A ironia é tematizada em termos éticos por Hegel na Filosofia do direito, §140, onde ela é a forma suprema da emancipação da subjetividade moral, isto é, a subjetividade que se coloca acima do bem e do mal e se apresenta como critério máximo do julgamento moral. Como conceito ético ela se torna possível com a filosofia de Fichte, na autolimitação do eu por um não eu posto pelo eu, embora tenha sido Friedrich Schlegel que tenha chegado à formulação de uma "particular egoidade" [besondere Ichheit]. ${ }^{31}$

Ainda no terreno histórico da arte, a ironia se apresenta como a expressão da dissolução do ideal da arte. Certamente ela designa o momento da absoluta negatividade, mas representa também a desintegração do ideal, sua desvinculação de um Conteúdo [Gehalt]. ${ }^{32}$ E nesse contexto dos Cursos de estética Hegel se refere a Novalis e sua timidez diante da efetividade, chamada de tísica do espírito. 
Na história da filosofia, o termo ironia surge, por sua vez, em Platão, mas apenas no plano da relação do diálogo entre as pessoas, nos chamados diálogos platônicos. Já o pensamento mesmo se orienta segundo a dialética, que se encontra acima da ironia. ${ }^{33}$ Em nota Hegel cita Solger, que teria tomado o conceito de ironia pelo lado do que é propriamente dialético nela, mas teria se equivocado ao estabelecer a ironia como o que é o mais elevado, numa resenha que Solger havia feito de uma obra de August Schlegel. Hegel discorda da posição de que o elevado está em nós como ironia trágica e considera que o trágico possui seu lugar mais próprio ou sua matriz teórica na eticidade e que na tragédia são potências éticas que se defrontam e não meras subjetividades. Desse modo, a ironia, como expressão da pura subjetividade, apenas falsamente pode ser colocada no lugar do ético, ou seja, o sujeito não pode ser o critério exclusivo da decisão do que é bom e verdadeiro. ${ }^{34}$

\section{O símbolo e a emancipação da imaginação}

Na verdade, o termo ironia, enquanto uma certa técnica de efetivação da subjetividade, possui sua origem mais própria na emancipação da imaginação $0^{35}$, como uma "segunda natureza" ${ }^{36}$ e a faculdade por excelência do ser humano. No começo da forma de arte simbólica dos Cursos de estética, Hegel aborda dois temas que eram centrais em sua época: o tema do símbolo e o da imaginação. Eram dois caminhos ou tópicos que serviam para afirmar a unidade do universal e do particular ou do sujeito e do objeto. Em sua juventude, em Fé e saber, marcado por Fichte e Schelling, Hegel se refere à imaginação produtiva, aquela desenvolvida por Kant na terceira crítica, em contraste com a imaginação meramente reprodutiva da primeira crítica, como sendo "uma verdadeira ideia especulativa". ${ }^{37}$

$\mathrm{Na}$ maturidade, ou melhor, desde o "Prefácio" à Fenomenologia do espírito, Hegel rebaixa o papel da imaginação por compreender que a mesma cria uma espécie de "mundo paralelo e abstrato" em relação ao real. Ora, o novelista E. T. A. Hoffmann considera, como narrador, em seu conto $O$ homem de areia, que esse mundo é mais verdadeiro do que o próprio real. Referindo-se ao destino do personagem central Natanael, o narrador afirma que "talvez você acredite, meu leitor, que nada é mais maravilhoso e louco do que a vida real e que o poeta pode apreendê-la apenas tal como num reflexo escuro em um espelho fracamente polido". ${ }^{38}$ Poder-se-ia aqui lembrar também do conto "Os autômatos", no qual um dos personagens centrais, Ferdinando, é de tal modo influenciado pela predição do autômato "Turco falante" que, na cena final, reage quase como sendo ele mesmo um autômato, embora desvairado, numa espécie de inversão de papéis, quando supõe que o Professor $X$ engendrou uma trama contra a sua noiva. Segundo seu amigo Ludwig, havia "um torvelinho em seu espírito". ${ }^{39}$

Nos Cursos de estética, por sua vez, no exame das colisões e situações típicas da arte, Hegel rejeita o gênero Märchen, tendo em vista que no mesmo o artista ou poeta se 
coloca numa posição equivocada, isto é, de que ele mesmo deve inventar, por meio de uma fantasia infinita, as situações que surgem em sua obra. "à primeira vista, pode parecer mais digno ao poeta [...] ser original e encontrar ele mesmo para si as situações, mas esta atividade própria não constitui nenhum aspecto essencial". ${ }^{40}$ Ao contrário, a configuração ética e espiritual e os grandes movimentos da alma e do caráter são mais decisivos do que esse elemento meramente subjetivo, de modo que a verdadeira atividade artística consiste antes em elaborar criativamente o que já está dado.

No que se refere ao pensamento simbólico, a posição de Hegel, embora concorde com seu colega Creuzer sobre a racionalidade imanente da mitologia ${ }^{41}$, procura ao mesmo tempo limitar o alcance do conceito de símbolo e mesmo de alegoria na arte, pois o símbolo é uma categoria que alcança seu sentido no interior do processo artístico como um todo e enquanto constitui um tipo de figuração, mas não enquanto é tomado como um paradigma de toda e qualquer arte. O argumento hegeliano é este: o símbolo, constituindo apenas uma parcela da figuração artística, mas não toda ela, há de ser interpretado pelo contexto maior da efetivação da arte, mas não o inverso - a arte ser submetida ao símbolo. Pois a arte possui ainda outras formas de efetivação, dentre elas a própria alegoria, que é o oposto do símbolo. Em suma, a arte se realiza por diferentes possibilidades figurativas que vão além da forma simbólica. O mesmo se aplica à categoria da alegoria, sendo, portanto, inadequada a afirmação de Friedrich Schlegel de que "toda beleza é alegoria". ${ }^{42}$

Além dessa questão categorial, Hegel ainda aponta para o limite e mesmo o término da configuração de tipo simbólico na arte, justamente quando na história a individualidade livre dos gregos, o sujeito, se torna significado nele mesmo e forma um todo, equilibrando assim o par: significado e expressão. ${ }^{43}$ Grosso modo, todo o campo ocupado pelo simbólico (a arte oriental) remete a algum tipo de predomínio do fantástico. Hegel, por exemplo, destaca o caráter fantasioso dos hindus, persas e egípcios.

\section{Conclusão: $O$ culto e a ironia}

À guisa de conclusão, eu gostaria de apontar para alguns aspectos do segundo artigo da resenha sobre Solger, os quais remetem para os fundamentos lógicos e especulativos da filosofia hegeliana. Não poderei aprofundar esse tema, mas ressalto que ele é decisivo para a exploração da noção de ironia. Se no primeiro artigo Hegel aborda a obra de Solger e o contexto romântico, enfatizando elementos estéticos, no segundo ele irá explorar o sentido religioso da ironia. Não se consegue compreender a crítica hegeliana à ironia sem passar pela filosofia da religião, a saber, pela abordagem da mitologia pelo viés de uma filosofia da religião.

Hegel afirma que Solger pensa a ironia como uma elevação ao divino e se refere a uma ironia trágica. ${ }^{44}$ No entanto, seria preciso considerar que a verdadeira elevação ao divino 
se chama de culto [Kultus], segundo a filosofia da religião de Hegel, o que implica uma elevação que ao mesmo tempo retorna à efetividade finita sem destruí-la, levando em conta o momento ético. ${ }^{45}$ No fim da "Introdução" aos Cursos sobre a filosofia da religião, Hegel identifica o culto com a dimensão mais elevada de Deus enquanto espírito universal e particular. No culto se realiza a singularidade da subjetividade e é superada a diferença entre o humano e o divino:

A esfera do culto significa dar a si realmente essa unidade, reconciliação, restabelecimento do sujeito e de sua consciência de si, o sentimento positivo da pertença, da pertença àquele absoluto e a unidade com o mesmo, em suma, a superação da cisão. O culto compreende todo esse atuar interior e exterior, que tem como finalidade esse restabelecimento para a unidade..$^{46}$

A diferença entre a ironia e o culto, como formas de elevação ao divino, é que o culto implica uma atitude que não se coloca no lugar do divino, do todo, e pretende ser uma espécie de ponto culminante da subjetividade válida intemporalmente. $O$ culto assume antes uma atitude mais humilde de reconciliação, de efetivação no seio da comunidade e da realidade, permitindo a legitimidade de um mundo ético. Se pensarmos na filosofia do direito de Hegel, poder-se-ia dizer que o culto é justamente aquela instância subjetiva no interior da moralidade que leva em conta a objetividade do mundo ético.

No §571 da Enciclopédia das ciências filosóficas, isto é, no último parágrafo que trata da passagem entre a figura da religião para a da filosofia, no âmbito do espírito absoluto, Hegel aborda a diferença entre o culto e a ironia. Esta é a expressão da subjetividade infinita que se tornou formal, porque nela não é o espírito que se sabe verdadeiramente a si mesmo em seu desdobramento objetivo desde a universalidade. ${ }^{47}$ Nesse ponto, a ironia se apresenta como inimiga tanto do desenvolvimento supremo da religião, o culto, quanto se pretende colocar no lugar do livre pensar filosófico. ${ }^{48} \mathrm{~A}$ ironia destrói a própria possibilidade da passagem do estado ético supremo para o livre pensar filosófico.

Mas, a verdadeira passagem da moralidade para a eticidade suprema é o culto, ou melhor, a moralidade necessita de um momento de crença, assim como o próprio pensar livre, de reconhecimento de que a instância da subjetividade não pode ser a instância última abstrata. O homem não pode viver o tempo todo no "gabinete da interioridade", seja ela irônica seja ela dominada por uma falta de senso religioso autêntico (a saber, a religião como fanatismo).

No caso da estética ou do campo da arte, região privilegiada desde a qual se nutre a ironia, Hegel adverte que a subjetividade na época moderna não pode encaminhar-se para uma mera estetização subjetiva do mundo e sim levar em conta que a atividade artística possui um limite inerente. A elevação é sem dúvida um momento culminante, mas ela não pode desconsiderar a efetividade de onde provém e, nessa medida, querer destruir essa efetividade pela ironia de um sujeito que imagina saber-se certo de si 
mesmo. ${ }^{49}$ Poder-se-ia estender esse ponto para o campo da história da arte, no sentido de que a arte do presente necessita ter uma ligação hermenêutica com a arte do passado. $\mathrm{O}$ fim da arte nos coloca diante dessa situação de que não podemos mais fazer arte sem ingressar no terreno da historicidade.

O tópico da relação entre o domingo e os dias da semana possui, portanto, várias implicações: 1) no campo estético, ele repõe a posição da arte diante da efetividade finita, da religião e da filosofia (presente nos Cursos de estética); 2) aponta para dialética entre o sujeito e a substância, entre o momento do despontar da subjetividade e sua relação com a efetividade, de que uma depende da outra. $O$ homem não pode viver apenas como se sempre fosse domingo (segundo o que sugerem os contos de Hoffmann e os Märchen em geral): isto é, no plano da ironia, da poesia da poesia, em suma, no plano de uma estetização geral da existência, desconsiderando a realidade, o público e os interesses da objetividade. Inversamente, não se trata também de apelar para um mundo em que tudo sempre é dia de semana (mundo do trabalho, da economia, pragmatismo, etc.). 3) Hegel propõe com essa fórmula uma troca de lugares entre o culto e a ironia, entre a subjetividade e a religião. Ou seja, postula uma elevação do conteúdo subjetivo que não recaia na abstração. No fundo, tocamos aqui também no problema da mitologia, a saber, da subjetividade que se eleva a si mesma como mito e que se reencontra na fantasia literária.

\footnotetext{
* Marco Aurélio Werle é professor do Departamento de Filosofia da USP.

1 "Solgers nachgelassene Schriften und Briefwechsel" In: HEGEL, G. W. F. Berliner Schriften. 1818-1831. Werke, v. 11. Frankfurt am Main: Suhrkamp, 1986, p. 258 [Doravante empregarei a sigla SSB para citar essa obra]. A contraposição exposta nessa epígrafe surge também na Filosofia da religião: dias de trabalho e o culto no domingo (Werke, v. 16, p. 16). A religião é o domingo da vida (idem, p. 12). Cf. igualmente a noção de especulativo (idem, p. 30).

2 Walter Jaeschke situa brevemente o perfil dessa revista na época em que Hegel atuava na Universidade de Berlim (Hegel Handbuch. Stuutgart; Weimar: J. B. Metzler, 2010, pp. 288-309). Trata-se de uma revista do grupo ligado a Hegel e na qual o próprio publicou resenhas sobre Wilhelm Von Humboldt, Hamann e Solger, dentre outros. Segundo Jaeschke, Hegel inaugurou inclusive um estilo de fazer resenhas, a partir do modo de procedimento de Humboldt, a saber, de sempre considerar o homem inteiro que está sendo resenhado e não apenas suas "idéias" ou concepções. Uma referência bibliográfica importante de comentários sobre os Jahrbücher é a coletânea organizada por Christoph Jamme: JAMME, C. (hrsg.) Die "Jahrbücher für wissenschaftliche Kritik". Hegels Berliner Gegenakademie. Suttgart-Bad Cannstatt: FrommanHolzboog, 1994.

${ }^{3}$ Cf. sobre isso a nota ao $\$ 140$ da Filosofia do direito (Tradução de Paulo Meneses e outros. São Leopoldo: Unisinos, 2010, p. 162). Mais adiante voltarei a esse trecho.

${ }^{4}$ HEGEL, G. W. F. SSB, p. 211.

${ }^{5}$ Ibidem, p. 212.

${ }^{6}$ Tratam-se principalmente das duas primeiras partes, concluídas em 1811-1812. Cf. sobre esse tema, o artigo de MONTEZ, L. B. "A obra autobiográfica de Goethe como relato historiográfico". In:
} 
Itinerários. Araraquara, n. 23 (2005), pp. 39-48.

${ }^{7}$ HEGEL, G.W.F. SSB, pp. 212-213,

${ }^{8}$ Ibidem, p. 213.

${ }^{9}$ Ibidem, p. 214.

${ }^{10}$ Cf. Ibidem, p. 220.

${ }^{11}$ Ibidem, p. 233. Hegel aborda o tema da ironia em obras como a Filosofia do direito (§140), na Enciclopédia das ciências filosóficas (§571), no fim da introdução aos Cursos de estética e na História da filosofia, no capítulo sobre a ironia socrática (cf. o comentário geral de Michael Inwood no Dicionário Hegel (Rio de Janeiro: Zahar, 1997, pp. 195-198).

12 Cap. VII: "A crítica da filosofia", pp. 172-173. In: SUZUKI, M. O gênio romântico. São Paulo: lluminuras, 1998. Observo ainda que Hegel tem em mente o romantismo como uma tendência ampla de pensamento, que tem suas raízes no pré-romantismo, ao passo que Márcio Suzuki considera o endereço da crítica hegeliana como se referindo exclusivamente ao primeiro romantismo, a saber, principalmente a Friedrich Schlegel.

${ }^{13}$ HEGEL, G. W. F. SSB, p. 218.

${ }^{14}$ RESKE, H. Traum und Wirklichkeit im Werk Heinrich von Kleists. Stuttgart: Kohlhammer, 1969, p. 92.

${ }^{15}$ SCHMIDT, J. Heinrich von Kleist. Die Dramen und Erzählungen in ihrer Epoche. Darmstadt: WBG, 2003, pp. 154-179.

16 Ibidem, p. 7.

${ }^{17}$ Nessa crítica hegeliana entre em jogo a posição de destaque do príncipe na teoria hegeliana do Estado moderno, presente na Filosofia do direito.

${ }^{18}$ Cursos de estética. v. II. São Paulo: EDUSP, 2000, p. 314.

${ }^{19}$ KLEIST, H. Michael Kohlhaas, o rebelde. Porto: Editorial Nova, 1973, p. 88; Werke und Briefe in vier Bänden. Edição organizada por Siegfried Streller. Berlin und Weimar: Aufbau, 1978, B. 3, p. 111.

${ }^{20}$ HEGEL, G. W. F. SSB, pp. 216-217.

${ }^{21}$ HEGEL, G. W. F. Cursos de estética. v. II. Op. cit., p. 329.

22 Ibidem.

${ }^{23}$ HEGEL, G. W. F. Cursos de estética. v. I. Tradução de Marco Aurélio Werle. São Paulo: EDUSP, 2001, p. 238.

${ }^{24}$ Ibidem, p. 239.

${ }^{25}$ Ibidem, p. 247.

${ }^{26}$ Ibidem, p. 248.

${ }^{27}$ Ibidem.

${ }^{28}$ Ibidem, pp. 81-83.

${ }^{29}$ HEGEL, G. W. F. SSB, p. 83.

${ }^{30}$ Nos Cursos de estética, Hegel localiza o que considera como sendo o verdadeiro fenômeno do cômico naqueles momentos históricos de transição e declínio, por exemplo, no fim do mundo grego com Aristófanes. 
${ }^{31}$ HEGEL, G. W. F. Werke 7, p. 286. Cf. também a tradução brasileira, p. 163, a qual, no entanto, não traduziu os adendos.

${ }^{32}$ HEGEL, G. W. F. Cursos de estética. v. I. Op. cit., p. 172.

${ }^{33}$ HEGEL, G. W. F. Werke 7. Op. cit., p. 277.

${ }^{34}$ Ibidem, p. 279.

${ }^{35}$ Cf. sobre esse ponto D'ANGELO, P. A estética do romantismo. Lisboa: Editorial Estampa, 1998.

${ }^{36}$ Essa concepção decorre de uma recepção romântica da teoria kantiana do gênio. Para Kant, "a faculdade da imaginação é [...] como que uma outra natureza a partir da matéria que a natureza efetiva Ihe dá". KANT, I. Crítica da faculdade do juízo. Tradução de Antonio Marques e Valério Rohden. Rio de Janeiro: Forense, 1995, §49, p. 159.

${ }^{37}$ HEGEL, G. W. F. Glauben und Wissen. In: Werke 2, p. 306.

${ }^{38}$ HOFFMANN, E. T. A. “Der Sandmann” In: Spukgeschichte und Märchen, p. 138.

${ }^{39}$ HOFFMANN, E. T. A. Contos fantásticos. Tradução de Cláudia Cavalcanti. Rio de Janeiro: Imago, 1993, p. 111.

${ }^{40}$ HEGEL, G. W. F. Cursos de estética. v. I. Op. cit., p. 222.

${ }^{41}$ HEGEL, G. W. F. Cursos de estética. v. II. Op. cit., p. 33.

${ }^{42}$ SCHLEGEL, F. Conversa sobre a poesia. Tradução de Victor Pierre Stirnimann. São Paulo: lluminuras, 1994, p. 58. Referida por Hegel nos Cursos de estética. v. II. Op. cit., p. 34.

${ }^{43}$ HEGEL, G. W. F. Cursos de estética. v. II. Op. cit., p. 35.

${ }^{44}$ HEGEL, G. W. F. SSB, p. 257.

${ }^{45}$ Ibidem, p. 258.

${ }^{46}$ HEGEL, G. W. F. Werke 16, pp. 71-72.

${ }^{47}$ HEGEL, G. W. F. Werke 10, p. 377.

${ }^{48}$ Ibidem, p. 378.

${ }^{49}$ HEGEL, G. W. F. SSB, p. 258. 